\title{
SOME DEFINING MOMENTS: CROSSING THE RUBICON
}

For readers of and contributors to Nationalities Papers, their common interest is in the fortunes and fates of ethnic groups in Eastern Europe and the territorium of the former Soviet Union. As those familiar with the lot of peoples in this polyglot region know, conditions can change abruptly and radically, from one day enjoying statehood to suffering minority status the next, or vice versa. A civil war or revolution, a war or the stroke of a diplomatic pen can trigger off fundamental changes. Such events are known as "defining moments," points on the chronological chart that allow one to speak in terms of "before" and "after." They serve as convenient references about which there is general consensus as to their overall significance, even though there may be heated dispute as to the specificity of their meaning.

In the individual history of an ethnic group there are always such defining moments or experiences that have captured the collective imagination as a major turning-point. The three Partitions of Poland are an example; the articles by Willis Brooks and Basil Dmytryshyn focus on similar critical moments as they impacted respectively on Ukrainians and the peoples of northern Caucasia. Which brings one to considerations of the chaotic present of 1995 and the preceding crystal clear dramatic watersheds of 1989-1991.

Viewed together, the years 1989-1995 generate simultaneously a sense of clarity and confusion. There is no question that 1989-the collapse of the Berlin Wall, and with it the entire Iron Curtain - and 1991 - the disintegration of the Soviet Union, and with it the birth of fifteen new states-definitively marked the end of an era that began in 1917-1920. There is little quarrel with 1989-1991 as a defining moment for all the nationalities of concern to this journal. There is, however, considerable debate over what has followed as each of the new and old/new countries embarked on their separate voyages into an uncharted future. For those unsure of what was happening after 1989-1991, it was convenient to leave the new chapter(s) unnamed except for a chronological tag, the "post-1989-1991 years."

For others, more certain of what would follow, the appellation "transition" proved illusionarily helpful. A transition model, however, requires two defining moments-a point A of departure (i.e., 1989-1991) and a point B of arrival. In this case, the transition model envisioned a two-track simultaneous evolution: from authoritarianism to democracy, and from a command economy to a market economy. The trouble with this neat transition formula is that it departs from a demonstrable given and moves towards an assumed common terminal point, leaving little room for mid-point adjustments or regional variations.

In the light of what has actually transpired since the 1989-1991 pivotal years, the 


\section{EDITORIAL}

utopian expectations encouraged by this optimistic transition model seem, at best, somewhat naïve. A more careful look at the chronological chart suggests, for example, three definitive moments that point to fundamentally different futures from those anticipated and articulated by the transitionalists. All three are violent events, and all three impact profoundly on the fortunes and fates of regional clusters of ethnicities, all three events having a core ethnic component. The defining moments indicative of new chapters following on the heels of 1989-1991 are (1) the Bosnian crisis, located in the epicenter of Yugoslav Balkanization; (2) the Nagorno-Karabakh conflict in the strategic center of southern or Trans-Caucasia; and (3) the RussoChechnyan War in the heart of northern or Mountain Caucasia. All three, more or less, broke out at the time of the 1989-1991 Raspad: Nagorno-Karabakh in 1988, when its regional government requested severance from Azerbaijan and unification with Armenia; Chechnya in 1991, when the government of President Dzhokhar Dudaev unilaterally declared independence from Russia; and Bosnia-Herzegovina in 1992, when Serbia and Croatia embarked together on the partitioning along ethnic lines of that vulnerable ex-Yugoslav republic.

Involvement in these bitter struggles have fundamentally determined the futures of the peoples of all three regions: (1) as a result of the war, Armenia and Azerbaijan have effectively mortgaged, if not bankrupted, their economies for several decades, and thoroughly corrupted both their political life and their civil societies, seriously putting their democratic futures into question; (2) the intractable war over Bosnia has forced Croatia and Serbia into a quagmire of ethno-rivalry headed by ethno-warlords that may last for generations and is leaving the entire multiethnic region from the border of Austria to the Aegean Sea with the constant threat of further ethnofragmentation and volatile instability; and (3), most serious on a global scale, are the already visible long-range consequences to the Russian Federation's political evolution for launching, perpetuating and justifying its full-scale war against tiny Chechnya. There is now no turning back from this fateful decision and its enormous costs. Yeltsin's choice to wage total war in Chechnya is the equivalent of Caesar's having crossed the Rubicon. It marks the death of genuine democracy in the Russian Federation, a fact not lost on the twenty-three non-Russian autonomous regions.

For those concerned with the emerging futures of the interlocked nations in these three regions, the three defining moments ought to be clear signals that there is far less liberal democracy and capitalism on the horizon than there are chronic ethnic strife and deepening xenophobia. All three events indicate all too clearly the futures following the 1989-1991 rupture from the Soviet/Communist past. Perhaps postRaspad chapters should now be named after each one of these defining moments. There are, of course, others; but how definitive are they? At least readers of and contributors to Nationalities Papers can be less uncertain about the outlines of the pasts, presents and near futures of the circumstances dictating the flow of events affecting the various ethnicities.

H.R.H. 